\title{
Ageing of atrazine in manure amended soils assessed by bioavailability to
} Pseudomonas sp. strain ADP

\author{
Glæsner, Nadia; Bælum, Jacob; Strobel, Bjarne W.; Jacobsen, Carsten S.
}

Published in:

Biodegradation

Link to article, DOI:

$10.1007 / \mathrm{s} 10532-013-9654-1$

Publication date:

2014

Document Version

Publisher's PDF, also known as Version of record

Link back to DTU Orbit

Citation (APA):

Glæsner, N., Bælum, J., Strobel, B. W., \& Jacobsen, C. S. (2014). Ageing of atrazine in manure amended soils assessed by bioavailability to Pseudomonas sp. strain ADP. Biodegradation, 25(2), 217-225.

https://doi.org/10.1007/s10532-013-9654-1

\section{General rights}

Copyright and moral rights for the publications made accessible in the public portal are retained by the authors and/or other copyright owners and it is a condition of accessing publications that users recognise and abide by the legal requirements associated with these rights.

- Users may download and print one copy of any publication from the public portal for the purpose of private study or research.

- You may not further distribute the material or use it for any profit-making activity or commercial gain

- You may freely distribute the URL identifying the publication in the public portal 


\title{
Ageing of atrazine in manure amended soils assessed by bioavailability to Pseudomonas sp. strain ADP
}

\author{
Nadia Glæsner • Jacob Bælum • \\ Bjarne W. Strobel · Carsten S. Jacobsen
}

Received: 4 February 2013/Accepted: 27 June 2013/Published online: 4 July 2013

(C) Springer Science+Business Media Dordrecht 2013

\begin{abstract}
Animal manure is applied to agricultural land in areas of high livestock production. In the present study, we evaluated ageing of atrazine in two topsoils with and without addition of manure and in one subsoil. Ageing was assessed as the bioavailability of atrazine to the atrazine mineralizing bacteria Pseudomonas sp. strain ADP. Throughout an ageing period of 90 days bioavailability was investigated at days 1,10 , 32,60 and 90 , where $\sim 10^{8}$ cells $\mathrm{g}^{-1}$ of the ADP strain was inoculated to the ${ }^{14} \mathrm{C}$-atrazine exposed soil and ${ }^{14} \mathrm{CO}_{2}$ was collected over 7 days as a measure of mineralized atrazine. Even though the bioavailable
\end{abstract}

N. Glæsner $(\bowtie) \cdot$ J. Bælum · C. S. Jacobsen

Department of Geochemistry, Geological Survey of

Denmark and Greenland (GEUS), Øster Voldgade 10,

1350 Copenhagen K, Denmark

e-mail: nadia.glaesner@gmail.com

N. Glæsner · B. W. Strobel · C. S. Jacobsen

Department of Plant and Environmental Sciences,

University of Copenhagen, Thorvaldsensvej 40,

1871 Frederiksberg C, Denmark

Present Address:

N. Glæsner

Directorate, Leibniz Centre for Agricultural Landscape

Research (ZALF), Eberswalder straße 84, 15374

Müncheberg, Germany

J. Bælum

Novo Nordisk Foundation Center for Biosustainability, Technical University of Denmark, Kogle Alle 4-6,

2970 Hørsholm, Denmark residue decreased in all of the three soils as time proceeded, we found that ageing occurred faster in the topsoils rich in organic carbon than in subsoil. For one topsoil rich in organic carbon content, Simmelkær, we observed a higher degree of ageing when treated with manure. Contrarily, sorption experiments showed less sorption to Simmelkær treated with manure than the untreated soil indicating that sorption processes are not the only mechanisms of ageing. The other topsoil low in organic carbon content, Ringe, showed no significant difference in ageing between the manure-treated and untreated soil. The present study illustrates that not simply the organic carbon content influences adsorption and ageing of atrazine in soil but the origin and composition of organic matter plays an important role.

Keywords Triazine - Animal manure - Ageing · Aging $\cdot$ Bioavailability $\cdot$ Sorption

\section{Introduction}

Application of animal manure has been a common worldwide practice for centuries in order to improve soil quality and increase essential plant nutrients in soil. Nowadays, land application of manure is a natural consequence in areas with high livestock densities. Organic matter in manure consists of both large hydrophobic parts and many carboxylic and phenolic groups to which sorption of pesticides may occur both 
by non-specific and specific sorption mechanisms (Plaza et al. 2002).

Increased organic material in soils has been reported to increase formation of aged pesticide residues (Chung and Alexander 2002). Ageing is defined by incorporation of a chemical compound into the soil matrix with increasing residence time. The mechanisms of ageing are not fully understood, but are agreed to occur concurrently by $(i)$ entrapment of molecules into micropores within minerals and soil organic matter inaccessible to microorganisms; (ii) absorption into the solid organic matter; (iii) or formation of strong chemical bonds to soil components largely resistant to desorption (Alexander 2000). Application of animal manure might therefore result in increased ageing of pesticides in soil and thereby increase accumulation over time.

The herbicide atrazine (2-chloro-4-ethylamino-6isopropylamino-1,3,5-triazine) is one of the most widely used herbicides in the world. Even though it is banned in several European countries it is still extensively used in e.g. the United States (US EPA 2006). Atrazine was banned in Denmark in 1994 but is still detected in Danish groundwater along with metabolites (Brüsch 2011). Ageing of atrazine has been reported in many topsoils which makes it less susceptible to degradation (Kruger et al. 1997; Radosevich et al. 1997; Johannesen and Aamand 2003). Ageing has previously been measured by reduced chemical extraction (Kelsey and Alexander 1997), reduced bioavailability to living organisms (Radosevich et al. 1997; Godskesen et al. 2005) or decreased sorption/desorption over time (Kruger et al. 1997). The ageing effect has been reported to vary between different soil types (Chung and Alexander 1998), where the soil organic carbon content (SOC) has been suggested to be the most important factor (Chung and Alexander 2002; Hang et al. 2005). Addition of animal manure to soil is reported to increase sorption of atrazine in different soils (Guo et al. 1991; Rouchaud et al. 1994; Businelli 1997), so we hypothesized that animal manure would increase ageing of atrazine in soil. We evaluated ageing by bioavailability of atrazine to the atrazine-degrading bacterium Pseudomonas sp. strain ADP, which possesses the genes atzABCDEF encoding the enzymes for rapid mineralization of atrazine (Mandelbaum et al. 1995; de Souza et al. 1996; BoundyMills et al. 1997; Sadowsky et al. 1998; Martinez et al. 2001). This approach allows direct measurement of bioavailability of atrazine to an inoculated bacterial strain, and is not based on chemical extractions. Studying bioavailability of pesticides is of importance for understanding the fate of pesticides in the soil environment and is not only related to ageing processes of pesticides.

The objective of the present study was to evaluate the effect of cattle manure on ageing of atrazine in two Danish agricultural topsoils with similar texture but differing in native organic carbon content. In comparison to the topsoils, one subsoil with very low organic carbon content was furthermore studied. In addition, sorption experiments were performed and discussed in relation to the ageing results.

\section{Materials and methods}

Soils and manure

Three Danish soils from two locations were studied. Samples from the topsoil layer $(0-20 \mathrm{~cm})$ (A horizon) of an agricultural fine sandy till soil from Ringe, Funen was sampled in March 2006 under frozen and wet conditions. This soil had been cultivated with maize continuously for more than 20 years with one annual addition of cattle manure and had a long history of atrazine exposure (1979-1995) and later terbuthylazine (1995-2006). Samples from the other location, Simmelkær, Jutland (coarse sandy alluvial soil) were taken from both the A horizon (upper $5 \mathrm{~cm}$ ) and C horizon (at $40 \mathrm{~cm}$ ). This soil had previously been cultivated with grain with one annual swine manure application and had no history of triazine herbicide application (Barlebo et al. 2005). Samples of fresh cattle manure (dry matter content of $11 \%$ ) were collected from a Danish agricultural farm and stored at $-18{ }^{\circ} \mathrm{C}$. Chemical analyses of the Ringe soil and the manure are described in Glæsner et al. (2010), and of the Simmelkær soil in Barlebo et al. (2005) and presented in Table 1. Prior to the beginning of the experiment the soils were acclimated at $10{ }^{\circ} \mathrm{C}$ for 1 week (Mortensen and Jacobsen 2004) and the manure for 1 day.

Preparation of bacterial culture

Pseudomonas sp. strain ADP cells were recovered by melting a full tube of uniform frozen cultures grown in a medium containing atrazine as the only source of $\mathrm{N}$. 
Table 1 Selected physical and chemical characteristics of the soils and manure

\begin{tabular}{|c|c|c|c|c|c|c|c|c|c|c|}
\hline \multirow[t]{2}{*}{ Soil } & \multirow[t]{2}{*}{ Depth $(\mathrm{cm})$} & \multicolumn{4}{|c|}{ Particle size $(\%)$} & \multirow[t]{2}{*}{$\mathrm{C}_{\text {tot }}(\%)$} & \multirow[t]{2}{*}{$\mathrm{N}_{\text {tot }}(\%)$} & \multirow[t]{2}{*}{$\mathrm{C} / \mathrm{N}$} & \multirow[t]{2}{*}{$\mathrm{pH}\left(\mathrm{H}_{2} \mathrm{O}\right)$} & \multirow[t]{2}{*}{$\mathrm{PH}\left(\mathrm{CaCl}_{2}\right)$} \\
\hline & & Clay & Silt & Fine sand & Coarse sand & & & & & \\
\hline RinA & $0-20$ & 2.8 & 6.8 & 41.4 & 49.0 & 0.95 & 0.09 & 10.2 & 6.0 & 5.2 \\
\hline $\operatorname{Sim}^{\mathrm{a}}$ & 5 & 3.3 & 2.9 & 8.5 & 85.3 & 2.58 & - & - & $7.0^{\mathrm{b}}$ & $4.6^{\mathrm{b}}$ \\
\hline $\operatorname{SimC}^{\mathrm{a}}$ & 40 & 2.5 & 0.9 & 17.3 & 79.1 & 0.19 & - & - & - & $5.8^{\mathrm{b}}$ \\
\hline Cattle manure & - & - & - & - & - & 41.9 & 2.55 & 18.3 & - & - \\
\hline $\operatorname{Rin} \mathrm{A}+$ & - & - & - & - & - & 1.36 & - & - & - & - \\
\hline $\operatorname{Sim} \mathrm{A}+$ & - & - & - & - & - & 2.97 & - & - & - & - \\
\hline
\end{tabular}

SimA Simmelkær A horizon, SimA+ Simmelkær A horizon with manure, SimC Simmelkær C horizon, RinA Ringe A horizon, RinA+ Ringe A horizon with manure

a Barlebo et al. 2005

b Measured at (1:1) ratio

The cell culture was grown in $250 \mathrm{~mL}$ blue cap flasks with $50 \mathrm{~mL}$ minimal salt (MS) medium (per $1 \mathrm{~L}$ : $1.36 \mathrm{~g} \quad \mathrm{KH}_{2} \mathrm{PO}_{4}, \quad 1.78 \mathrm{~g} \quad \mathrm{Na}_{2} \mathrm{HPO}_{4} \cdot 2 \mathrm{H}_{2} \mathrm{O}, \quad 0.05 \mathrm{~g}$ $\mathrm{KNO}_{3}, 0.05 \mathrm{MgSO}_{4} \cdot 7 \mathrm{H}_{2} \mathrm{O}, 0.0132 \mathrm{~g} \mathrm{CaCl}_{2} \cdot 2 \mathrm{H}_{2} \mathrm{O}$, $2.86 \mathrm{mg} \mathrm{H}_{3} \mathrm{BO}_{3}, 1.54 \mathrm{mg} \mathrm{MnSO}_{4} \cdot \mathrm{H}_{2} \mathrm{O}, 0.039 \mathrm{mg}$ $\mathrm{CuSO}_{4} \cdot 5 \mathrm{H}_{2} \mathrm{O}, \quad 0.021 \mathrm{mg} \quad \mathrm{ZnCl}_{2}, \quad 0.041 \mathrm{mg}$ $\mathrm{CoCl}_{2} \cdot 6 \mathrm{H}_{2} \mathrm{O}, 0.025 \mathrm{mg} \quad \mathrm{Na}_{2} \mathrm{MoO}_{4} \cdot 2 \mathrm{H}_{2} \mathrm{O}, 5.14 \mathrm{mg}$ $\left.\mathrm{FeCl}_{2} \cdot 6 \mathrm{H}_{2} \mathrm{O}\right)$ and citrate $\left(1 \mathrm{~g} \mathrm{~L}^{-1}\right)$ as the only source of C. Prior to addition of MS medium, $5 \mathrm{mg}$ atrazine (Dr. Ehrenstorfer, Augsburg, Germany) dissolved in acetonitrile was $\mathrm{N}_{2}$-dried in the bottom of the flasks giving a final concentration of $100 \mathrm{mg} \mathrm{L}^{-1}$. Further, ${ }^{14} \mathrm{C}$-atrazine (Sigma, MO, U.S.) in trace amount was added to ensure that bacterial growth could be linked to mineralization of atrazine. The culture was incubated at $20{ }^{\circ} \mathrm{C}$ and shaken at $150 \mathrm{rpm}$ for exactly $48 \mathrm{~h}$ and growth was determined by measuring the optical density $\left(\mathrm{OD}_{600}\right)$. The culture was centrifuged for $10 \mathrm{~min}(8,500 \times g)$ and washed twice in phosphatebuffer $(0.1 \mathrm{M}, \mathrm{pH} 7.4)$. Finally, the culture was dissolved in $25 \mathrm{~mL}$ MS medium without $\mathrm{N}$. The number of bacterial cells was calculated by tenfold dilution drop-plating (Herigstad et al. 2001) on R2A agar (Difco).

\section{Ageing experiment}

Ageing of atrazine was studied during a period of 90 days of incubation at five occasions (days of sampling; day 1, 10, 32, 60 and 90). The soils studied were the A and $C$ horizon of Simmelkær (SimA and SimC), the A horizon of Ringe (RinA) and both A horizons with added manure $(\operatorname{Sim} A+$ and $\operatorname{Rin} A+)$.
$15 \mathrm{~g}$ (wet weight, 70-80\% water content of field capacity) of soil in $100 \mathrm{~mL}$ autoclaved airtight glass flasks was spiked with $1 \mathrm{~mL}$ of $1.5 \mathrm{mg} \mathrm{L}^{-1}$ atrazine (Dr. Ehrenstorfer, Augsburg, Germany) (purity of $99.5 \%$ ) solution in milliQ water containing trace amounts U-ring- ${ }^{14} \mathrm{C}$-atrazine (Sigma, MO, U.S.) (purity $95 \%$; specific activity of $695.6 \mathrm{MBq}$ $\mathrm{mmol}^{-1}$ ). Addition of this solution made a final concentration of $0.1 \mathrm{mg}$ atrazine $\mathrm{kg}^{-1}$ soil and 15,000 DPM per flask. The samples were set up in triplicates plus one control sample for each soil with addition of milliQ water only, giving a total number of 80 flasks ( 5 soils, 5 days of sampling, triplicates, 1 control soil per day of sampling). To the soil-manure samples, $1 \mathrm{~mL}$ of $150 \mathrm{mg} \mathrm{mL}^{-1}$ homogenized cattle manure was added to SimA+ and RinA+ one day prior to atrazine application. The added manure reflected the normal scenario of a Danish agricultural field with a concentration of 30 tons ha ${ }^{-1}$ (Ministry of Environment 2006).

Mineralization was measured by placing a glass vial containing $2 \mathrm{~mL}$ of $0.5 \mathrm{M} \mathrm{NaOH}$ to each soil sample to trap the released $\mathrm{CO}_{2}$. Samples were incubated at $15^{\circ} \mathrm{C}$ in the dark and the $\mathrm{NaOH}$ traps were replaced every 7-14 days in a sterile hood and simultaneously aerating the flasks to avoid anaerobic conditions. The $\mathrm{NaOH}$ including the trapped ${ }^{14} \mathrm{CO}_{2}$ was transferred to scintillation vials containing $10 \mathrm{~mL}$ scintillation fluid (Wallac Scintillation Products, Turku, Finland) and counted for $10 \mathrm{~min}$ on a liquid scintillation counter (Wallac 1409, Turku, Finland) and corrected for background radioactivity. At the days of sampling, the soils dedicated for the actual day were spiked with 
$1 \mathrm{~mL}$ of $2-4 \times 10^{9}$ Pseudomonas sp. ADP cells $\mathrm{mL}^{-1}$. The bacterial inoculation lasted 7 days during which the alkali traps were replaced daily.

\section{Sorption experiment}

One gram of air dried soil sample was mixed with $9 \mathrm{~mL}$ of $0.01 \mathrm{M} \mathrm{CaCl}_{2}$ and equilibrated for $24 \mathrm{~h}$ in $10 \mathrm{~mL}$ centrifuge glass tubes at $15{ }^{\circ} \mathrm{C}$. After equilibration $1 \mathrm{~mL}$ of $0.01 \mathrm{M} \mathrm{CaCl}_{2}$ with atrazine (included ${ }^{14} \mathrm{C}$-atrazine) was added to give final concentrations of $0,0.1,0.5,1,5$ and $10 \mathrm{mg} \mathrm{L}^{-1}$ and a radioactivity of 2,000 DPM per tube. The tubes were set up in triplicates. The glass tubes were rotated in the dark at $15^{\circ} \mathrm{C}$ for $96 \mathrm{~h}$ at $20 \mathrm{rpm}$ and afterwards centrifuged for $30 \mathrm{~min}(2,700 \times g)$ (Jacobsen et al. 2008). $1 \mathrm{~mL}$ of the supernatant was mixed with $4 \mathrm{~mL}$ of scintillation fluid (Wallac Scintillation Products, Turku, Finland) and counted for $10 \mathrm{~min}$ on a liquid scintillation counter (Wallac 1409, Turku, Finland). Manure and soil were initially thoroughly mixed in the manure treated samples. The $\mathrm{pH}$ of the samples was measured after the experiment. All sorption isotherms were linear and the distribution coefficient was obtained by:

$$
K_{d}=\frac{C(\mathrm{~s})}{C(\mathrm{aq})}
$$

where $\mathrm{K}_{\mathrm{d}}$ is the distribution constant, $\mathrm{C}(\mathrm{s})\left(\mathrm{mg} \mathrm{kg}^{-1}\right)$ is the concentration of adsorbed atrazine, and $\mathrm{C}(\mathrm{aq})$ $\left(\mathrm{mg} \mathrm{L}^{-1}\right)$ is the solution concentration of atrazine. We furthermore calculated the partitioning coefficient, $\mathrm{K}_{\mathrm{oc}}$, by:

$K_{O C}=\frac{K_{d}}{f_{O C}}$

where $\mathrm{f}_{\mathrm{oc}}$ is the fraction of organic carbon.

\section{Data analysis}

Statistics carried out on the ageing results were performed using two- and three-way analysis of variance (ANOVA) and on the sorption results using linear regression with the program Statistical Analysis System version 9.1 (SAS Institute, Cary, NC, U.S.). $F$ tests were carried out on the mineralization curves using a first-order model and a three-half-order model after Mortensen and Jacobsen (2004) to see which model best fitted the data.

\section{Results and Discussion}

Ageing of atrazine assessed by bioavailability to Pseudomonas sp. strain ADP

Inoculation with Pseudomonas sp. strain ADP to all incubation times in the five scenarios confirmed that atrazine mineralization proceeded by 1 st order kinetics in deficient of a lag phase (Fig. 1; Table 2). This was expected as the bacteria possessed the ability of rapid atrazine mineralization and had been preexposed to the compound before inoculation to the soils.

Ageing of atrazine increased with increasing time as mineralization decreased with increasing time in both the SimA topsoil and the SimC subsoil (Fig. 2). In SimA $\sim 80 \%$ of ${ }^{14} \mathrm{C}$-atrazine was mineralized already after 1 day. Mineralization of ${ }^{14} \mathrm{C}$-atrazine in SimA decreased significantly $(P<0.001)$ throughout the duration of the ageing experiment and the pattern suggests a continuous decline in bioavailability with a longer ageing period (Fig. 2). SimC showed a similar mineralization $(\sim 75 \%)$ after 1 day of aging. The following pattern of SimC differed greatly from SimA as no significant change in mineralized atrazine was observed between 0 and 10 days of aging $(P=0.35)$. After 32 days of aging mineralization declined significantly $(P<0.05)$ compared to 1 and 10 days of aging, after which, mineralization did not change significantly $(P>0.05)$ and remained at a fixed level $\sim 25 \%$ lower than the initial value until the end of the experiment.

Other studies have also found a higher degree of atrazine as well as triazine amine ageing in topsoils compared to subsoils (Kruger et al. 1997; Hang et al. 2005; Godskesen et al. 2005), which has been related to a larger fraction of organic matter in A horizons (Chung and Alexander 2002). Bound residues of atrazine have been found to be present in the fraction with highest organic matter content in several studies (Barriuso and Koskinen 1996; Loiseau and Barriuso 2002; Hang et al. 2005; Mahía and Díaz-Raviña 2007). In the present study, the carbon contents were $2.58 \%$ in the A horizon and $0.19 \%$ in the $\mathrm{C}$ horizon (Table 1). Large carbon content is a major source of micropores which are abundant in the organic fraction of soil (Plaza et al. 2002). The hydrophobic surfaces of the organic fraction in the micropores adsorb hydrophobic molecules, which is one accepted mechanism 
Fig. 1 Percentage of $\left[{ }^{14} \mathrm{C}\right]$ atrazine mineralized by the inoculated

Pseudomonas sp. strain ADP cells $\left(10^{8}\right.$ cells $\mathrm{g}^{-1}$ for 7 days) in two topsoils (SimA, RinA) and a subsoil (SimC) in the 7 days following inoculation. The different symbols represent the days after addition of atrazine (1, 10, 32, 60 and 90 days). SimA+ and RinA + were treated with $10 \mathrm{~g} \mathrm{~kg}^{-1}$ cattle manure. $\operatorname{SimA~Simmelkær~A~horizon,~}$ $\operatorname{Sim} A+$ Simmelkær A horizon with manure, RinA Ringe A horizon, RinA+ Ringe A horizon with manure. SimC Simmelkær C horizon. The data are fitted to a 1 st order model, $\mathrm{P}=\mathrm{S}_{0} \times\left(1-\mathrm{e}^{-\mathrm{k} \times \mathrm{t}}\right)$; and the kinetic parameters are given in Table 2

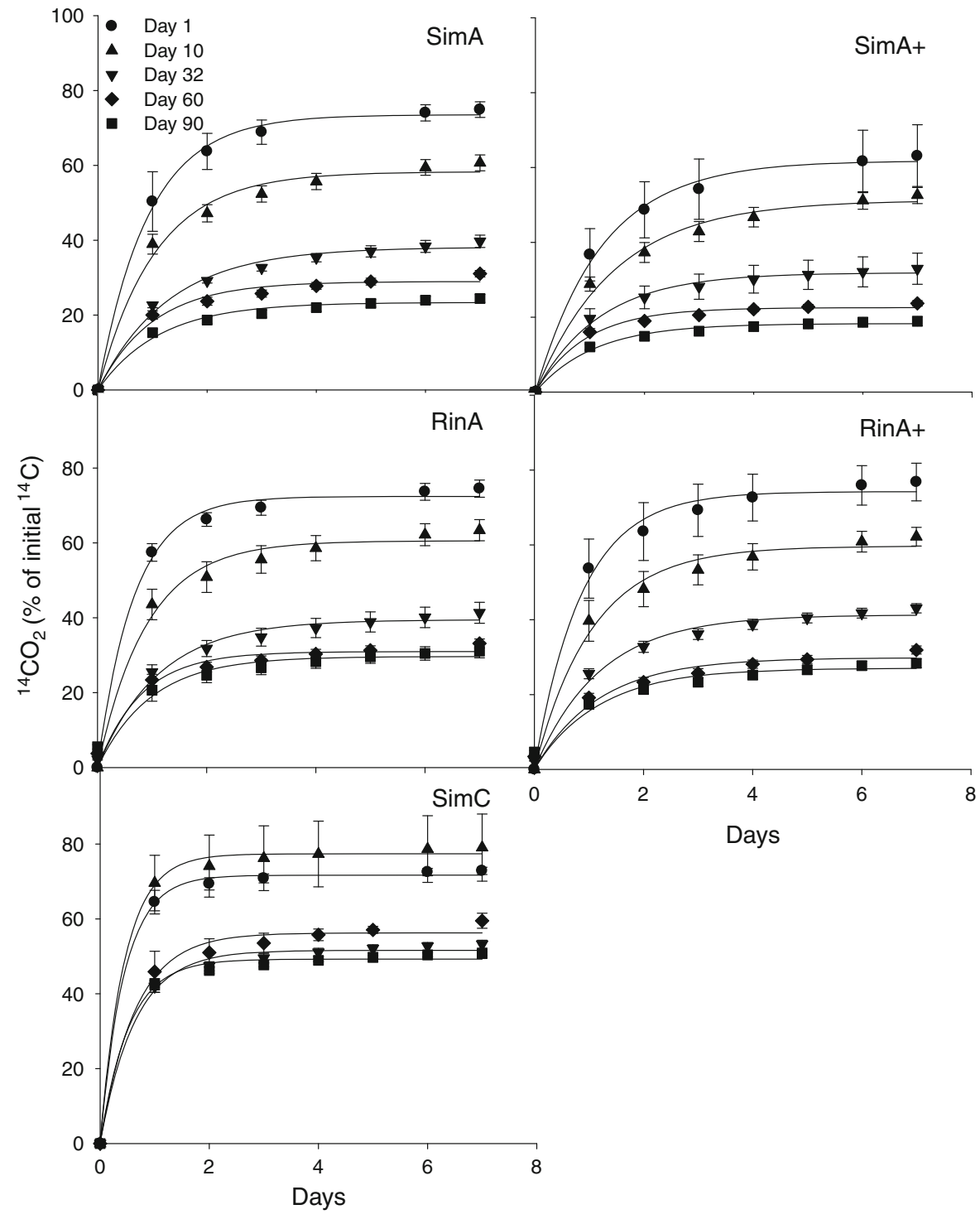

Table 2 Kinetic parameters of the percentage of $\left[{ }^{14} \mathrm{C}\right]$ atrazine mineralized by the inoculated Pseudomonas sp. strain ADP cells $\left(10^{8}\right.$ cells $\mathrm{g}^{-1}$ for 7 days) fitted to a $1^{\text {st }}$ order model,
$\mathrm{P}=\mathrm{S}_{0} \times\left(1-\mathrm{e}^{-\mathrm{k} \times \mathrm{t}}\right) ; \mathrm{S}_{0}$ is the maximal mineralization and $\mathrm{k}$ is the mineralization rate (Fig. 1)

\begin{tabular}{|c|c|c|c|c|c|c|c|c|c|c|c|c|c|c|c|}
\hline \multirow[t]{2}{*}{ Soil } & \multicolumn{3}{|c|}{ Day 1} & \multicolumn{3}{|c|}{ Day 10} & \multicolumn{3}{|c|}{ Day 32} & \multicolumn{3}{|c|}{ Day 60} & \multicolumn{3}{|c|}{ Day 90} \\
\hline & $\begin{array}{l}\mathrm{S}_{0} \\
(\%)\end{array}$ & $\begin{array}{l}\mathrm{k} \\
\left(\mathrm{d}^{-1}\right)\end{array}$ & $R^{2}$ & $\begin{array}{l}\mathrm{S}_{0} \\
(\%)\end{array}$ & $\begin{array}{l}\mathrm{k} \\
\left(\mathrm{d}^{-1}\right)\end{array}$ & $R^{2}$ & $\begin{array}{l}\mathrm{S}_{0} \\
(\%)\end{array}$ & $\begin{array}{l}\mathrm{k} \\
\left(\mathrm{d}^{-1}\right)\end{array}$ & $R^{2}$ & $\begin{array}{l}\mathrm{S}_{0} \\
(\%)\end{array}$ & $\begin{array}{l}\mathrm{k} \\
\left(\mathrm{d}^{-1}\right)\end{array}$ & $R^{2}$ & $\begin{array}{l}\mathrm{S}_{0} \\
(\%)\end{array}$ & $\begin{array}{l}\mathrm{k} \\
\left(\mathrm{d}^{-1}\right)\end{array}$ & $R^{2}$ \\
\hline $\operatorname{Sim} A$ & 73.5 & 1.09 & 0.98 & 58.3 & 0.95 & 0.98 & 38.1 & 0.77 & 0.98 & 29.0 & 0.99 & 0.98 & 23.4 & 0.89 & 0.97 \\
\hline $\operatorname{SimA}+$ & 61.8 & 0.82 & 0.93 & 51.3 & 0.70 & 0.98 & 31.9 & 0.84 & 0.93 & 22.6 & 1.09 & 0.99 & 18.3 & 0.94 & 0.97 \\
\hline SimC & 71.7 & 2.25 & 0.99 & 77.4 & 2.23 & 0.94 & 51.6 & 1.57 & 0.99 & 56.3 & 1.56 & 0.98 & 49.3 & 1.90 & 0.98 \\
\hline $\operatorname{Rin} A$ & 72.4 & 1.49 & 0.99 & 60.6 & 1.11 & 0.97 & 39.5 & 0.90 & 0.96 & 31.0 & 1.25 & 0.95 & 29.7 & 1.03 & 0.88 \\
\hline $\operatorname{Rin} \mathrm{A}+$ & 74.2 & 1.15 & 0.95 & 59.7 & 0.94 & 0.97 & 41.3 & 0.84 & 0.98 & 29.8 & 0.85 & 0.95 & 27.0 & 0.86 & 0.91 \\
\hline
\end{tabular}

. SimA Simmelkær A horizon, SimA+ Simmelkær A horizon with manure, SimC; Simmelkær C horizon, RinA Ringe A horizon, RinA+ Ringe A horizon with manure 


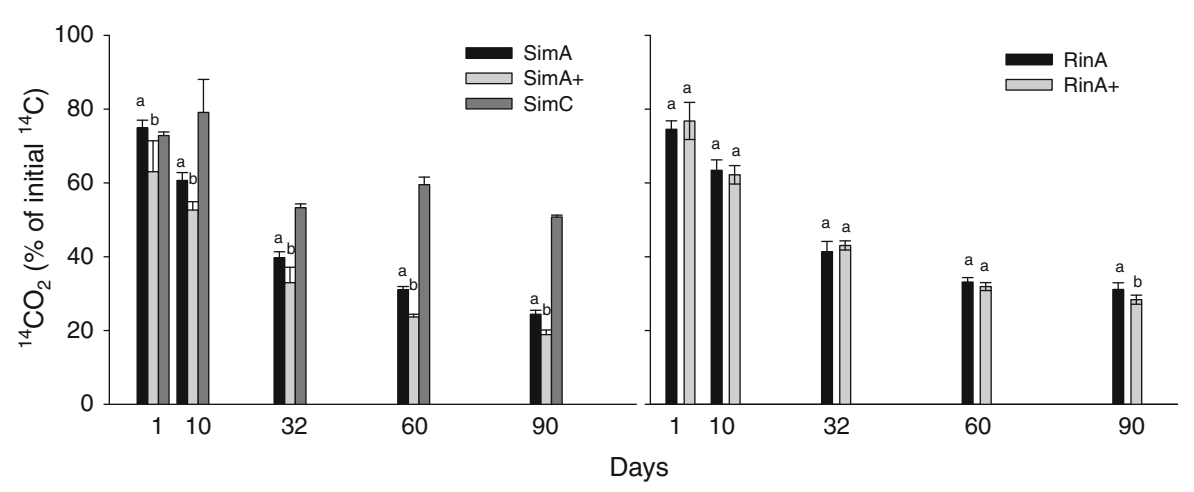

Fig. 2 Percentage of ${ }^{14} \mathrm{C}$-atrazine mineralized by the inoculated Pseudomonas sp. strain ADP cells $\left(10^{8}\right.$ cells $\mathrm{g}^{-1}$ for 7 days) in two topsoils with and without application of $10 \mathrm{~g} \mathrm{~kg}$ ${ }^{-1}$ cattle manure at five sampling days during an ageing period of 90 days. a Simmelkær soil, SimA without manure (black

of ageing. This could explain the continuous decline in bioavailable atrazine with time in the carbon rich topsoil, as the high organic content continuously aged more and more atrazine with time. In the same time, the stagnant level of bioavailable atrazine after 32 days in the subsoil could be a result of low organic matter content, where some ageing occurred in the beginning of the experiment. Here after the non-aged atrazine was bioavailable for the inoculated bacteria as sorption sites at the organic matter became saturated over time.

Other factors influencing mineralization are availability of nutrients, humidity, and the population of the Pseudomonas sp. strain ADP. Indigenous soil microbial community can furthermore cause formation of intermediate metabolites of atrazine which become unsusceptible to mineralization by the Pseudomonas sp. strain ADP.

The two topsoil scenarios, SimA and RinA, showed a significant difference in availability of atrazine residues to Pseudomonas sp. strain ADP $(P<0.05)$; RinA mineralized a higher percentage of ${ }^{14} \mathrm{C}$-atrazine than SimA. This could be explained by the higher organic carbon content in SimA than RinA (Table 1) which may have made atrazine less available in SimA. Another explanation could be the previous history of exposure to triazine herbicides in RinA which may have accelerated the mineralization of the applied atrazine. In a previous study, RinA showed higher mineralization of atrazine compared with SimA caused by indigenous soil microbial community, bars), SimA + with manure (light gray bars), SimC (dark gray bars). b Ringe soil, RinA without manure (black bars), RinA+ with manure (light gray bars). The data are the same as shown in Fig. 1, but here presented to get a better overview of the ageing effect after manure application

however the mineralization potential was very low in both soils; not exceeding $3 \%$ of added atrazine in RinA and $<1 \%$ in SimA (Glæsner et al. 2010), hence this is not expected to have caused the observed differences in this study.

\section{Effect of manure on ageing}

The two topsoils, Simmelkær A and Ringe A, were treated with manure corresponding to a concentration of 30 tons $\mathrm{ha}^{-1}$, as is commonly used in Danish agricultural practice (Ministry of Environment 2006). Manure was added to the two topsoils to evaluate the effect of manure on ageing of atrazine in soils (Fig. 2). In general, the percentage of mineralized ${ }^{14} \mathrm{C}$-atrazine in SimA+ decreased with time similar to SimA, but the addition of manure resulted in significantly less mineralized ${ }^{14} \mathrm{C}$-atrazine at all ageing days $(P<0.001)$ indicating less bioavailable atrazine in this soil when treated with manure. The lower availability in SimA + compared to SimA can be related to the increased organic matter added to the soil (Chung and Alexander 2002). Interestingly, for RinA and RinA+ soil scenarios the percentage of mineralized ${ }^{14} \mathrm{C}$-atrazine declined throughout the ageing experiment, as was observed for SimA, but no significant effect of manure was observed $(P=0.86)$ in the Ringe soil. Aguilera et al. (2009) and Briceño et al. (2010) found no effect of liquid cow manure amendment on atrazine degradation to high carbon soils pre-exposed to the herbicide, whereas 
Cheyns et al. (2012) found lower atrazine mineralization after adding pig manure and Dolaptsoglou et al. (2007) found poultry compost and urban sewage sludge to retard degradation of terbuthylazine in low carbon soils. Hence, our results as well as the literature indicate that manure does not increase ageing of atrazine in all soils or for all types of organic matter.

It should be mentioned, that the mineralization efficiency of Pseudomonas sp. strain ADP might have been influenced as well by the manure application. Manure application can create a favourable nutrient rich environment for the inoculated bacteria which could lead to multiplication of cells of Pseudomonas sp. strain ADP, but may as well create a stressful environment for the inoculated bacteria which could lead to reduction of cells of Pseudomonas sp. strain ADP (Unc and Goss 2004).

\section{Sorption}

As sorption is one of the main processes of ageing of chemicals in soil, sorption isotherms were carried out in the five soils after $96 \mathrm{~h}$ of incubation and showed linear sorption isotherms with low $\mathrm{K}_{\mathrm{d}}$ values ranging from 0.3 to 5.4 (Table 3, Fig. 3). The $\mathrm{K}_{\mathrm{d}}$ values of the $\mathrm{A}$ and $\mathrm{C}$ horizons are in agreement with other studies in agricultural soils $\left(\mathrm{K}_{\mathrm{d}}\right.$ 0.1-6.3) (Seybold and Mersie 1996; Celis et al. 1998; Wenk et al. 1998; Jacobsen et al. 2001; Boivin et al. 2005; Dolaptsoglou et al. 2007; Cabrera et al. 2008) although a direct comparison does not evaluate differences in methodology between these studies. The C-horizon showed lower potential of sorption than the A horizons explained by the lower content of organic carbon as the $\mathrm{K}_{\mathrm{oc}}$ values are in the same range. This is in agreement with the higher bioavailability of atrazine in the $\mathrm{C}$ horizon (Figs. 1, 2). In RinA (0.95\% C) we observed a significantly lower sorption than in $\operatorname{SimA}(2.58 \% \mathrm{C})$, and addition of cattle manure $10 \mathrm{~g} \mathrm{~kg}^{-1}$ to the $\mathrm{A}$ horizons resulted in less sorption of atrazine in both topsoils (Table 3). Hence, we found lower sorption despite increased organic carbon content in the soils treated with cattle manure (Table 1). All $\mathrm{K}_{\mathrm{d}}$ values obtained were low and atrazine was weakly sorbed in all soils, and the lower $\mathrm{K}_{\mathrm{d}}$ value obtained for the manure amended Simmelkær and Ringe soils were equal to $K_{d}$ values found in agricultural topsoils in general (mentioned above). Earlier studies have revealed organic matter to increase adsorption of atrazine in soils (Rouchaud et al. 1994; Businelli 1997; Celis et al. 1998; Cabrera et al. 2008). However, easily degradable soil carbon sources has been reported to lower the distribution constant of atrazine depending on fractionation of humic and fulvic acids (Celis et al. 1998; Houot et al. 2000), and as manure is considered an easily degradable carbon source (Entry and Emmingham 1995; Plaza et al. 2002), this might explain the decline in the $K_{d}$ value with addition of cattle manure. Furthermore, atrazine might have adsorbed to the dissolved organic fraction of the manure treated soils, which is then measured in the solution fraction and contributes to a lower $K_{d}$ value observed in the manure treated soils.

$\mathrm{K}_{\mathrm{oc}}$ is useful as a normalization of adsorption values in soil, assuming that SOC is the primary adsorbing phase in soil and has similar sorption properties in all soils. Variations in $\mathrm{K}_{\mathrm{oc}}$ values represent deviations from the described assumptions. Calculated $\mathrm{K}_{\mathrm{oc}}$ values 209 and 200 for SimA and RinA respectively (Table 3 ), almost eliminated the difference in adsorption for the two topsoils, and values are within the range of $\mathrm{K}_{\mathrm{oc}}$ values of 83-278 in the literature (Seybold and Mersie 1996). For the manure amended soils (with higher organic matter content, Table 1), the calculated $\mathrm{K}_{\mathrm{oc}}$ values were 118-138 for the topsoils, much lower than the unamended soils, showing that the composition of organic matter is of great importance in the adsorption of atrazine in soil.

Atrazine bioavailability showed an enhanced formation of aged residues in Simmelkær with addition of manure (Fig. 2), but we found at the same time that sorption decreased in the manure amended soil, which

Table 3 Distribution coefficient $\left(\mathrm{K}_{\mathrm{d}}\right)$ and partitioning coefficient $\left(\mathrm{K}_{\mathrm{oc}}\right)$ for sorption of atrazine in the five soils studied

\begin{tabular}{lll}
\hline Soil & $\mathrm{K}_{\mathrm{d}}$ & $\mathrm{K}_{\mathrm{oc}}\left(\mathrm{L} \mathrm{kg}^{-1}\right)$ \\
\hline SimA & $5.4 \pm 0.54$ & $209 \pm 21$ \\
SimA+ & $4.1 \pm 0.41$ & $138 \pm 14$ \\
SimC & $0.3 \pm 0.05$ & $158 \pm 26$ \\
RinA & $1.9 \pm 0.11$ & $200 \pm 12$ \\
RinA+ & $1.6 \pm 0.17$ & $118 \pm 13$ \\
\hline
\end{tabular}

SimA Simmelkær A horizon, SimA+ Simmelkær A horizon with manure, $\operatorname{Sim} C$ Simmelkær C horizon, RinA Ringe A horizon, $\operatorname{Rin} A+$ Ringe A horizon with manure 
Fig. 3 Sorption isotherms of atrazine to two soil with and without amended manure. SimA Simmelkær A horizon, $\operatorname{Sim} A+$ Simmelkær A horizon with manure, $\operatorname{Sim} C$ Simmelkær C horizon. RinA Ringe A horizon, RinA+ Ringe A horizon with manure. Calculated $\mathrm{K}_{\mathrm{d}}$ values presented in Table 3

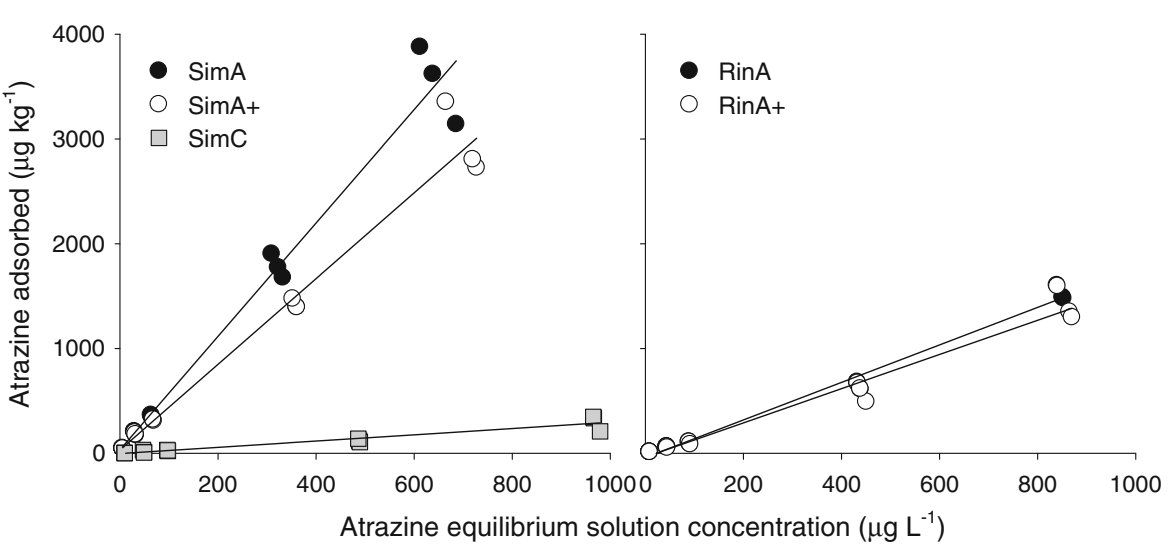

indicates that sorption cannot entirely explain the formation of aged residues.

Acknowledgments This study was funded by the Danish Research Council (FTP no. 274-05-0199).

\section{References}

Addition of atrazine to soils at a concentration of $0.1 \mathrm{mg} \mathrm{kg}^{-1}$ resulted in ageing of atrazine during a 90 day incubation experiment in two topsoils treated with and without cattle manure and to a lesser extent in a subsoil (without manure addition). Ageing was assessed by the bioavailability of atrazine to Pseudomonas sp. strain ADP, and the bioavailability declined throughout the experiment. The subsoil showed decreased bioavailability after 32 days, thereafter the bioavailability remained constant, which may be a result of saturation of ageing sites in this soil with low organic matter content.

One topsoil with high organic matter content, Simmelkær, revealed greater ageing effect upon cattle manure amendment, whereas the Ringe topsoil with low organic matter content did not show any effect of manure application on ageing of atrazine. Hence, a generalization of the impact of manure on ageing of atrazine in agricultural soils is not possible. Including more soils in future studies might further shed light on the role of manure on ageing of atrazine in soil.

We found lower sorption of atrazine in Simmelkær with manure than without manure treatment. This indicates that sorption alone does not explain formation of aged residues in soil, and that the composition rather than the actual content of organic matter is of major importance in adsorption and ageing of atrazine in soil.
Aguilera P, Briceño G, Candia M, Mora ML, Demanet R, Palma G (2009) Effect of dairy manure rate and the stabilization time of amended soils on atrazine degradation. Chemosphere 77:785-790

Alexander M (2000) Aging, bioavailability, and overestimation of risk from environmental pollutants. Environ Sci Technol 34:4259-4265

Barlebo HC, Ernstsen V, Jacobsen CS, Vosgerau H, Jacobsen $\mathrm{OH}$, Olesen SE (2005) Concept for determinations of pesticide sensitive areas. Ministry of Environment, Geological Survey of Denmark and Greenland, GEUS. In Danish

Barriuso E, Koskinen WC (1996) Incorporating nonextractable atrazine residues into soil size fractions as a function of time. Soil Sci Soc Am J 60:150-157

Boivin A, Cherrier R, Schiavon M (2005) A comparison of five pesticides adsorption and desorption processes in thirteen contrasting field soils. Chemosphere 61:668-676

BoundyMills KL, deSouza ML, Mandelbaum RT, Wackett LP, Sadowsky MJ (1997) The atzB gene of Pseudomonas sp. strain ADP encodes the second enzyme of a novel atrazine degradation pathway. Appl Environ Microbiol 63: 916-923

Briceño G, Jorquera MA, Demanet R, Mora ML, Durán N, Palma G (2010) Effect of cow slurry amendment on atrazine dissipation and bacterial community structure in an agricultural Andisol. Sci Total Environ 408:2833-2839

Brüsch W (2011) Pesticides. In: Thorling L (ed) Groundwater monitoring 1990-2010. Geological Survey of Denmark and Greenland, In Danish

Businelli D (1997) Pig slurry amendment and herbicide coapplication effects on s-triazine mobility in soil: an adsorption-desorption study. J Environ Qual 26:102-108

Cabrera A, Cox L, Koskinen WC, Sadowsky MJ (2008) Availability of triazine herbicides in aged soils amended with olive oil mill waste. J Agr Food Chem 56:4112-4119 
Celis R, Barriuso E, Houot S (1998) Effect of liquid sewage sludge addition on atrazine sorption and desorption by soil. Chemosphere 37:1091-1107

Cheyns K, Martin-Laurent F, Bru D, Aamand J, Vanhaecke L, Diels J, Merckx R, Smolders E, Springael D (2012) Long-term dynamics of the atrazine mineralization potential in surface and subsurface soil in an agricultural field as a response to atrazine applications. Chemosphere 86:1028-1034

Chung NH, Alexander M (1998) Differences in sequestration and bioavailability of organic compounds aged in dissimilar soils. Environ Sci Technol 32:855-860

Chung N, Alexander M (2002) Effect of soil properties on bioavailability and extractability of phenanthrene and atrazine sequestered in soil. Chemosphere 48:109-115

de Souza ML, Sadowsky MJ, Wackett LP (1996) Atrazine chlorohydrolase from Pseudomonas sp. strain ADP: gene sequence, enzyme purification, and protein characterization. J Bacteriol 178:4894-4900

Dolaptsoglou C, Karpouzas DG, Menkissoglu-Spiroudi U, Eleftherohorinos I, Voudrias EA (2007) Influence of different organic amendments on the degradation, metabolism, and adsorption of terbuthylazine. J Environ Qual 36:1793-1802

Entry JA, Emmingham WH (1995) The influence of dairy manure on atrazine and 2,4-dichlorophenoxyacetic acid mineralization in pasture soils. Can J Soil Sci 75:379-383

Glæsner N, Bælum J, Strobel BW, Jacobsen CS (2010) Atrazine is not readily mineralised in 24 temperate soils regardless of pre-exposure to triazine herbicides. Environ Pollut 158:3670-3674

Godskesen B, Holm PE, Jacobsen OS, Jacobsen CS (2005) Aging of triazine amine in soils demonstrated through sorption, desorption, and bioavailability measurements. Environ Toxicol Chem 24:510-516

Guo L, Bicki TJ, Hinesly TD, Felsot AS (1991) Effect of carbonrich waste materials on movement and sorption of atrazine in a sandy, coarse-textured soil. Environ Toxicol Chem 10:1273-1282

Hang S, Barriuso E, Houot S (2005) Atrazine behavior in the different pedological horizons of two Argentinean non-till soil profiles. Weed Res 45:130-139

Herigstad B, Hamilton M, Heersink J (2001) How to optimize the drop plate method for enumerating bacteria. J Microbiol Meth 44:121-129

Houot S, Topp E, Yassir A, Soulas G (2000) Dependence of accelerated degradation of atrazine on soil $\mathrm{pH}$ in French and Canadian soils. Soil Biol Biochem 32:615-625

Jacobsen CS, Shapir N, Jensen LO, Jensen EH, Juhler RK, Streibig JC, Mandelbaum RT, Helweg A (2001) Bioavailability of triazine herbicides in a sandy soil profile. Biol Fertil Soils 33:501-506

Jacobsen CS, van der Keur P, Iversen BV, Rosenberg P, Barlebo H, Torp S, Vosgerau H, Juhler RK, Rasmussen J, Brinch UC, Jacobsen OH (2008) Variation of MCPA, metribuzine, methyltriazine-amine and glyphosate degradation, sorption, mineralization and leaching in different soil horizons. Environ Pollut 156:794-802

Johannesen H, Aamand J (2003) Mineralization of aged atrazine, terbuthylazine, 2,4-D, and mecoprop in soil and aquifer sediment. Environ Toxicol Chem 22:722-729
Kelsey JW, Alexander M (1997) Declining bioavailability and inappropriate estimation of risk of persistent compounds. Environ Toxicol Chem 16:582-585

Kruger EL, Rice PJ, Anhalt JC, Anderson TA, Coats JR (1997) Comparative fates of atrazine and deethylatrazine in sterile and nonsterile soils. J Environ Qual 26:95-101

Loiseau L, Barriuso E (2002) Characterization of the atrazine's bound (nonextractable) residues using fractionation techniques for soil organic matter. Environ Sci Technol 36: 683-689

Mahía J, Díaz-Raviña M (2007) Atrazine degradation and residues distribution in two acid soils from temperate humid zone. J Environ Qual 36:826-831

Mandelbaum RT, Allan DL, Wackett LP (1995) Isolation and characterization of a Pseudomonas sp. that mineralizes the s-triazine herbicide atrazine. Appl Environ Microbiol 61:1451-1457

Martinez B, Tomkins J, Wackett LP, Wing R, Sadowsky MJ (2001) Complete nucleotide sequence and organization of the atrazine catabolic plasmid pADP-1 from Pseudomonas sp. strain ADP. J Bacteriol 183:5684-5697

Ministry of Environment (2006) Notice of commercial keeping of animals, animal manure, silage. National Environmental Protection Agency, Denmark. In Danish

Mortensen SK, Jacobsen CS (2004) Influence of frozen storage on herbicide degradation capacity in surface and subsurface sandy soils. Environ Sci Technol 38:6625-6632

Plaza C, Senesi N, Garcia-Gil JC, Brunetti G, D’Orazio V, Polo A (2002) Effects of pig slurry application on soils and soil humic acids. J Agric Food Chem 50:4867-4874

Radosevich M, Traina SJ, Tuovinen OH (1997) Atrazine mineralization in laboratory-aged soil microcosms inoculated with s-triazine-degrading bacteria. J Environ Qual 26:206214

Rouchaud J, Gustin F, Cappelen O, Mouraux D (1994) Pig slurry and cow manure effect on atrazine and metolachlor soil biodegradation in maize. Bull Environ Contam Toxicol 52:568-573

Sadowsky MJ, Tong ZK, de Souza M, Wackett LP (1998) AtzC is a new member of the amidohydrolase protein superfamily and is homologous to other atrazine-metabolizing enzymes. J Bacteriol 180:152-158

Seybold CA, Mersie W (1996) Adsorption and desorption of atrazine, deethylatrazine, deisopropylatrazine, hydroxyatrazine, and metolachlor in two soils from Virginia. J Environ Qual 25:1179-1185

Unc A, Goss MJ (2004) Transport of bacteria from manure and protection of water resources. Appl Soil Ecol 25:1-18

US EPA (2006) Finalization of atrazine interim reregistration eligibility decision, and completion of tolerance reassessment and reregistration. Decision documents for atrazine. www.epa.gov

Wenk M, Baumgartner T, Dobovsek J, Fuchs T, Kucsera J, Zopfi J, Stucki G (1998) Rapid atrazine mineralization in soil slurry and moist soil by inoculation of an atrazinedegrading Pseudomonas sp. strain. Appl Microbiol Biotechnol 49:624-630 